\title{
Keratinocyte growth factor-induced proliferation of rat airway epithelium is restricted to Clara cells in vivo
}

\author{
H. Fehrenbach*, A. Fehrenbach", T. Pan`, M. Kasper ${ }^{+}$, R.J. Mason
}

Keratinocyte growth factor-induced proliferation of rat airway epithelium is restricted to Clara cells in vivo. H. Fehrenbach, A. Fehrenbach, T. Pan, M. Kasper, R.J. Mason. (C) ERS Journals Ltd 2002.

ABSTRACT: Keratinocyte growth factor (KGF) is a potent mitogen of pulmonary bronchial and alveolar epithelial cells. However, it is unclear which type(s) of airway epithelial cells (AEC) proliferate(s) in response to KGF.

AEC proliferation was induced in rats by either endobronchial instillation of $5 \mathrm{mg}$ recombinant human ( $\mathrm{rHu}$ ) KGF per $\mathrm{kg}$ body weight or by adenoviral transfer of the human KGF gene (Ad5-HuKGF). Alterations in terminal airway AEC were followed for up to 7 days after rHuKGF, and for up to 28 days after Ad5-HuKGF.

Cell proliferation, as assessed by immunohistochemistry (IHC) for incorporated 5bromo-2'-deoxyuridine (BrdU) and quantified by stereology, peaked at days 1-2 and was resolved by day 7 after rHuKGF and by day 21 after Ad5-HuKGF. Double immunofluorescence labelling for BrdU or $\mathrm{Ki}-67$ on the one hand, and for Clara cell specific protein $10(\mathrm{CC10})$ and calcitonin-gene related peptide on the other hand, demonstrated that Clara cells, not pulmonary neuroendocrine cells, proliferated in response to human KGF. TUNEL (terminal deoxynucleotidyl transferase-mediated deoxyuridine triphosphate nick end-labelling) method in conjunction with IHC for MNF116 failed to detect significant numbers of apoptotic AEC. IHC in conjunction with stereology revealed transient phenotypic alterations with a decrease in $\mathrm{CC10}$, an increase in surfactant protein $D$ and an increase in CD44v6 in AEC.

The authors conclude that Clara cells responded to human keratinocyte growth factor in vivo by proliferation as well as by changes in protein expression, whereas no significant response was observed in pulmonary neuroendocrine cells. As Clara cells are intimately involved in airway epithelial repair, ion and fluid transport, and modulate lung inflammation, the potential of human keratinocyte growth factor to protect the lung may in part rely on the response of Clara cells.

Eur Respir J 2002; 20: 1185-1197.
*Clinical Research Group "Chronic Airway Diseases", Philipps-University, Marburg, "Center of Anatomy, University Clinics, Georg-August-University, Göttingen, and Institute of Anatomy, University Clinics "Carl Gustav Carus", Technical University of Dresden, Dresden, Germany. "National Jewish Medical and Research Center, Denver, CO, USA.

Correspondence: H. Fehrenbach, Clinical Research Group "Chronic Airway Diseases", Philipps-University, Baldingerstrasse, D-35033 Marburg, Germany. Fax: 49 64212868987

E-mail: heinz.fehrenbach@mailer. uni-marburg.de

Keywords: Airway epithelium, Clara cells, keratinocyte growth factor, neuroepithelial cells, progenitor cells, proliferation

Received: April 202002

Accepted after revision: June 122002

This work was supported by a grant from the National Institutes of Health, USA (HL-56556), and by the Bundesministerium für Bildung und Forschung, Germany (01ZZ5904).
Keratinocyte growth factor (KGF) is a member of the fibroblast growth factor (FGF) family that specifically binds to the KGF receptor, the IIIb splice variant of FGF receptor 2. As FGF receptor $2 \mathrm{IIIb}$ is mainly expressed in epithelium, KGF specifically stimulates epithelial cells to proliferate $[1,2]$. In the lung, KGF (also known as FGF-7) is a potent mitogen of alveolar epithelial type II cells in vitro [3, 4] and in vivo [5-8]. Kinetics of the incorporation of 5-bromo-2'-deoxyuridine (BrdU) into alveolar cells shows that hyperplasia of type II cells peaks at about 2-3 days after treatment with human recombinant $(\mathrm{rHu}) \mathrm{KGF}$ (rHuKGF) given via the airways [5]. As was comprehensively reviewed by WARE and MATTHAY [2], pre-treatment with $\mathrm{rHuKGF}$ protects the lung against a variety of lung injuries e.g. acid instillation [9], $\alpha$-naphthylthiourea [10], hyperoxia [11], hydrostatic pulmonary oedema [12] and bleomycin [13]. The mechanisms that are thought to contribute to the protective effect of $\mathrm{rHuKGF}$ include enhancement of alveolar repair, upregulation of alveolar epithelial fluid transport [14, 15], modulation of the alveolar coagulation/fibrinolysis system [11], and inhibition of alveolar epithelial cell apoptosis [16-18]. However, very little is known about the potential contribution of the conducting airway epithelium to rHuKGF-related mechanisms of lung protection [19-21].

Although, in their initial paper, ULICH et al. [5] demonstrated that $\mathrm{rHuKGF}$ induced airway epithelial cell proliferation in rat lungs in vivo, little is known about which airway cells respond and their physiological alterations. rHuKGF induces proliferation of bronchial epithelial cells in primary culture and bronchial cell lines such as Calu-3, BEAS-2B and 4MBR-5 cells $[22,23]$. Polymerase chain reaction and northern blot analyses demonstrated the presence of transcripts of the KGF receptor in foetal and adult rat lung [24], as well as in primary cultures of normal human bronchial epithelial cells and in the bronchial epithelial cell line BEAS-2B [23]. Transgenic mice that express human KGF under the control of the Clara cell secretory protein $10 \mathrm{kD}(\mathrm{CC} 10)$ promoter upon doxycycline administration exhibited marked 
transient airway epithelial hyperplasia with thickening of the columnar epithelium and frequent transitions to a pseudostratified epithelium [8]. YANO et al. [21] indicated that after instillation of rHuKGF in vivo, the bronchiolar epithelium responds with altered protein expression, i.e. an increase in surfactant protein D (SP-D), and a decrease in CC10. Nothing is known, however, about changes of the membrane-bound adhesion molecule CD44v6, which has been implicated in cell-cell and cell-matrix interactions as well as in airway epithelial repair $[25,26]$. Since CD44v6 is present in pulmonary stem cells of epithelial origin but not in cells of neuroendocrine lineage [27], CD44v6 may serve as an additional marker to evaluate the origin of the cells proliferating in response to $\mathrm{KGF}$.

KGF was shown to alter gene expression in primary human airway epithelial cells in vitro [28]. In particular, KGF decreased transcripts for many interferon-induced genes, which suggests that it may dampen the response of epithelial cells to inflammatory mediators. However, the airway epithelium is composed of a number of different cell types displaying distinctive structural and functional characteristics that may vary from species to species, e.g. the greater number of Clara cells in the larger airways of the lungs of rodents as compared with humans [29]. While these previous studies document cellular changes in response to human KGF, it remains unclear which type(s) of airway epithelial cells proliferate(s) in response to rHuKGF in vivo and how their phenotype is altered.

Therefore, the purpose of this study was to investigate the proliferative response of specific airway epithelial cell types to human KGF. The effect of human KGF was studied using two in vivo models of transiently induced pulmonary epithelial cell proliferation. First, rHuKGF-protein was instilled via the left main bronchus to induce short-term hyperplasia, which resolves within 1 week $[5,7,13]$. In a second model, the human KGF gene was introduced by instillation of a replication-deficient human type 5 adenovirus vector expressing human $\mathrm{KGF}$ to induce epithelial cell hyperplasia, which may persist for up to 3 weeks [30].

\section{Material and methods}

\section{Endobronchial instillation of recombinant human keratinocyte growth factor}

Anaesthetised Fisher 344 rats were intubated orally, and instilled with rHuKGF or phosphate-buffered saline (PBS) into the left lung only, as described previously [9, 13]. rHuKGF (kindly provided by Amgen Inc, Thousand Oaks, CA, USA) was given as a single bolus at a dose of $5 \mathrm{mg} \cdot \mathrm{kg}$ bodyweight ${ }^{-1}$ diluted in $300 \mu \mathrm{L}$ PBS followed by a single inflation of $0.5 \mathrm{~mL}$ air. Control animals received an equivalent volume of $300 \mu \mathrm{L}$ PBS. Two animals per group were sacrificed 1, 2, 3 and 7 days after treatment. The humane care and use of all experimental animals in this study was overseen by the Local Animal Use and Care Review Committee. All animals were treated according to the respective guidelines, which were in compliance with the "Guide for the Care and Use of Laboratory Animals" published by the National Institutes of Health (NIH publication 85-23, revised 1985).

\section{Adenoviral-mediated transfer of the human keratinocyte growth factor gene}

As described recently [30], Fisher 344 rats received a bolus of $1 \times 10^{9}$ instilled plaque-forming units of replication-deficient human type 5 adenovirus vector expressing human KGF (Ad5-HuKGF), Ad5-LacZ or PBS. One animal per time-point was examined at day 2, 3, 7, 14, 21 and 28 after gene transfer.

\section{Fixation}

Lungs were perfused with PBS ( $\mathrm{pH} 7.4)$ via the right ventricle and subsequently instilled via the trachea with $4 \%$ paraformaldehyde in PBS. The left lung was cut into equidistant slices, which were embedded in paraffin [7].

\section{Immunohistochemistry}

Paraffin sections were stained according to indirect immunohistochemistry, as described previously [7, 18, 25]. After antigen retrieval (table 1), dewaxed sections were incubated with hydrogen peroxide and 50\% foetal calf serum (FCS) in PBS prior to incubation with the primary antibodies used at the appropriate dilution (table 1). After washing with PBS, polyclonal antibodies were detected by incubation with peroxidase-coupled goat anti-rabbit immunoglobulin G (HRP77; H. Grossmann, Dresden, Germany) at a 1:400 dilution in PBS containing 50\% FCS followed by diaminobenzidine. For monoclonals, a mouse kit based on the avidin-biotin peroxidase complex technique (Vectastain Elite kit; Vector Laboratories, Burlinghame, CA, USA) was used. Finally, sections were counterstained with haematoxylin.

\section{Double immunofluorescence staining}

Dewaxed paraffin sections were washed in PBS, incubated with primary antibody, labelled with 4, 6-dichlorotriazinyl-aminofluorescein, and incubated with the Texas red-labelled second antibody [31]. Sections mounted in glycerol-PBS (9:1) containing 2.5\% 1,4-Diazobicyclo-2.2.2. Octane (DABCO; Janssen, Beerse, Belgium) were examined with an Olympus BH-2 fluorescence microscope (Olympus, Tokyo, Japan).

\section{Assessment of apoptosis}

As described in detail elsewhere [7, 31], the terminal deoxynucleotidyl transferase (TdT)-mediated 
Table 1. - Antibodies, lectins and kits used to investigate parenchymal alterations in rat lungs instilled with recombinant human keratinocyte growth factor

\begin{tabular}{|c|c|c|c|c|c|}
\hline Marker & $\begin{array}{l}\text { Main } \\
\text { specificity }\end{array}$ & $\begin{array}{l}\text { Type of } \\
\text { marker }\end{array}$ & Origin & $\begin{array}{l}\text { Dilution, } \\
\text { antigen retrieval }\end{array}$ & $\begin{array}{l}\text { Detection } \\
\text { system }\end{array}$ \\
\hline CC10 & Clara cells & $\begin{array}{l}\text { Rabbit anti-rat } \\
\text { polyclonal antibody }\end{array}$ & $\begin{array}{l}\text { Dr. Klug } \\
\text { (Marburg, } \\
\text { Germany) }\end{array}$ & 1:1000 Microwave & $\begin{array}{l}\text { Peroxidase-coupled } \\
\text { goat anti-rabbit } \\
\text { IgG }\end{array}$ \\
\hline CGRP & $\begin{array}{l}\text { Neuroendocrine } \\
\text { cells }\end{array}$ & Monoclonal & Sigma/RBI & 1:100 Microwave & $\mathrm{ABC}$ \\
\hline SP-D & $\begin{array}{l}\text { Clara cells, } \\
\text { alveolar type II } \\
\text { cells, alveolar } \\
\text { macrophages }\end{array}$ & $\begin{array}{l}\text { Mouse anti-rat } \\
\text { monoclonal } \\
\text { antibody (clone CA/19) }\end{array}$ & $\begin{array}{l}\text { S. Albrecht } \\
\text { (Dresden, } \\
\text { Germany) }\end{array}$ & $\begin{array}{l}\text { Undiluted } \\
\text { Microwave }\end{array}$ & $\begin{array}{l}\text { Peroxidase-coupled } \\
\text { goat anti-rabbit } \\
\text { IgG }\end{array}$ \\
\hline Pan-cytokeratin & $\begin{array}{l}\text { Pulmonary } \\
\text { epithelial cells }\end{array}$ & $\begin{array}{l}\text { Mouse anti-human } \\
\text { monoclonal antibody } \\
\text { (clone MNF116) }\end{array}$ & Dako & 1:150 Pronase & APAAP \\
\hline Cytokeratin 18 & $\begin{array}{l}\text { Airway brush } \\
\text { cells, alveolar } \\
\text { type III cells }\end{array}$ & $\begin{array}{l}\text { Mouse anti-human } \\
\text { monoclonal antibody } \\
\text { (clone Ks18.04) }\end{array}$ & Progen & 1:20 Pronase & $\mathrm{ABC}$ \\
\hline CD44v6 & $\begin{array}{l}\text { Airway epithelial } \\
\text { cells, alveolar } \\
\text { type II cells, }\end{array}$ & $\begin{array}{l}\text { Mouse anti-rat } \\
\text { monoclonal antibody } \\
\text { (clone } 1.1 \text { AMSL) }\end{array}$ & $\begin{array}{l}\text { U. Günthert } \\
\text { (Basel, } \\
\text { Switzerland) }\end{array}$ & Undiluted & $\mathrm{ABC}$ \\
\hline BrdU & $\begin{array}{l}\text { Proliferating } \\
\text { cells (S-phase) }\end{array}$ & $\begin{array}{l}\text { Mouse anti-rat } \\
\text { monoclonal antibody }\end{array}$ & Dako & 1:100 Microwave & $\mathrm{ABC}$ \\
\hline $\mathrm{Ki}-67$ & $\begin{array}{l}\text { Proliferating } \\
\quad \text { cells (cell cycle) }\end{array}$ & $\begin{array}{l}\text { Mouse anti-rat } \\
\text { monoclonal antibody } \\
\text { (MIB-5) }\end{array}$ & Dinanova & 1:5 Microwave & $\mathrm{ABC}$ \\
\hline TUNEL & $\begin{array}{l}\text { Apoptotic } \\
\text { cells }\end{array}$ & TdT, dUTP & $\begin{array}{l}\text { Oncor, } \\
\text { Appligene }\end{array}$ & & $\mathrm{DAB}$ \\
\hline
\end{tabular}

CC10: Clara cell specific protein 10; CGRP: calcitonin gene-related peptide; SP-D: surfactant protein D; BrdU: 5-bromo-2'deoxyuridine; TUNEL: terminal deoxynucleotidyl transferase-mediated deoxyuridine triphosphate nick end-labelling; TdT: terminal deoxynucleotidyl transferase; dUTP: deoxyuridine triphosphate; Ig: immunoglobulin; ABC: avidin-biotin peroxidase complex; APAAP: alkaline phosphatase-antialkaline phosphatase labelling; DAB: diaminobenzidine.

deoxyuridine triphosphate nick end-labelling (TUNEL) method was used to demonstrate apoptosis in dewaxed paraffin sections using the ApopTag peroxidase apoptosis detection S7100-kit (Oncor-Appligene, New York, NY, USA). Control sections were identically treated with only TdT being omitted in the primary incubation step. TUNEL-stained sections were subsequently stained according to the alkaline phosphatase-antialkaline phosphatase labelling method with the monoclonal anti-cytokeratin antibody MNF116(DAKO, Hamburg, Germany), an established marker of epithelial cells.

\section{Stereology}

To quantify alterations of the airway epithelium after rHuKGF-treatment, sections stained for BrdU, CC10 and SP-D, respectively, were analysed using a personal computer-based system (CAST Grid; Olympus, Albertslund, Denmark). All airway profiles identified in all slices were traced to represent the inclusion area from which the fields of view were collected according to a software-integrated systematic random sampling scheme. Each field of view was superimposed with a test line grid. Intersections of test lines with total basal membrane (IEpi) as well as with basal membrane covered by BrdU-, CC10- or SP-D-stained airway epithelial cells (Iantigen) were counted, respectively. The fraction of the airway epithelial basal membrane covered by the respective immunoreactive cell population was calculated according to the following equation:

$$
\text { Ss }(\text { antigen,Epi })=\sum \text { Iantigen } / \sum \text { IEpi }
$$

\section{Statistics}

Stereological estimates of airway epithelial alterations are given as discrete values for each lung. The level of significance of an effect of human KGF versus PBS was tested by analysis of variance and partial correlation analysis. A p-value of 0.05 was considered significant.

\section{Results}

Both endobronchial instillation of rHuKGFprotein and Ad5-HuKGF resulted in a remarkable increase in proliferating airway epithelial cells (fig. 1). The proliferative response could be demonstrated by immunohistochemical detection of BrdU incorporated into the nuclei during S-phase as well as by immunostaining for $\mathrm{Ki67}$, a nuclear proliferation marker expressed throughout the cell cycle (fig. 2). The fraction of airway epithelial surface covered by BrdU-positive cells was highest at day 1 after rHuKGF instillation and gradually declined to zero at day 7 (fig. 3). After adenoviral transfer of the human KGF-gene, the degree of proliferation on day 2 was similar to instillation of $\mathrm{rHuKGF}$-protein 


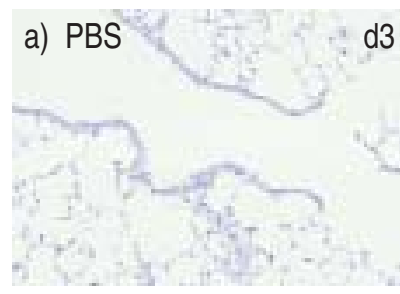

e) $P B S$
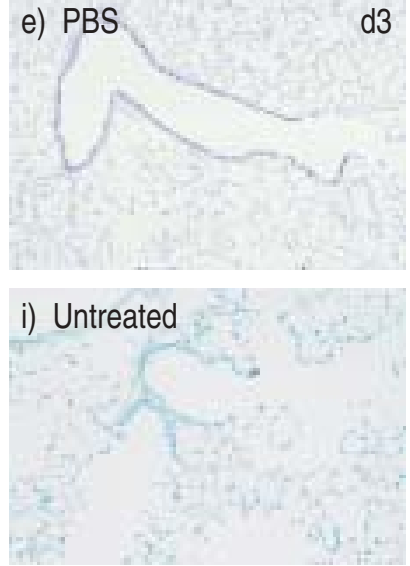

m) PBS
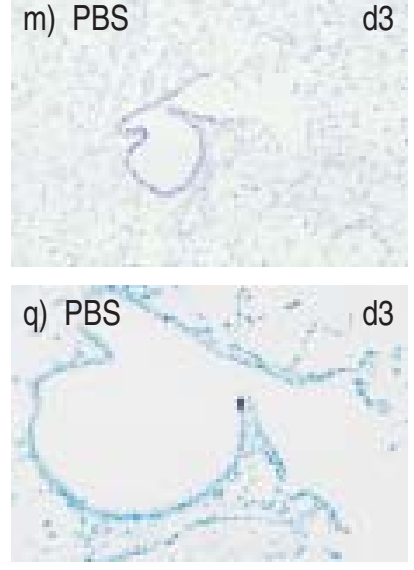

3
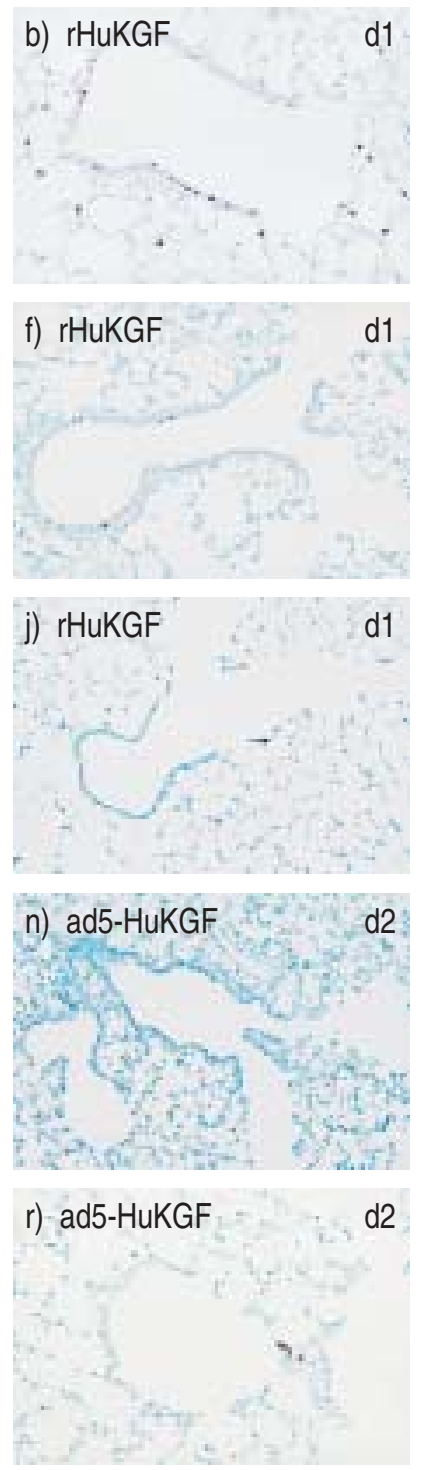

d1
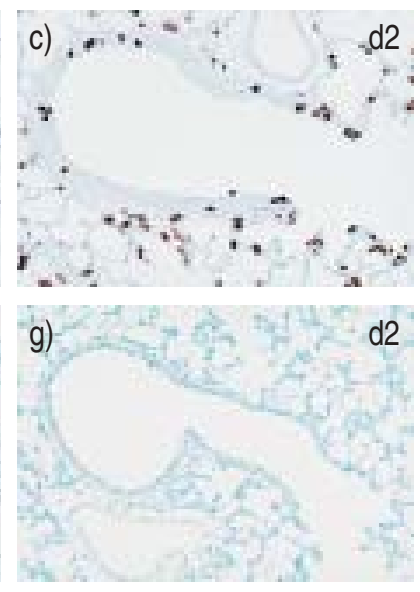

d2 h)

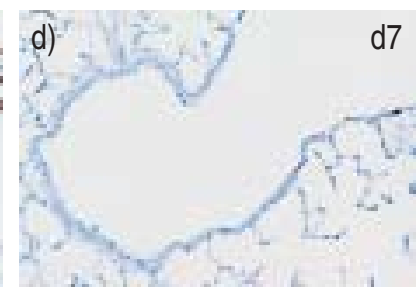

h)

d7
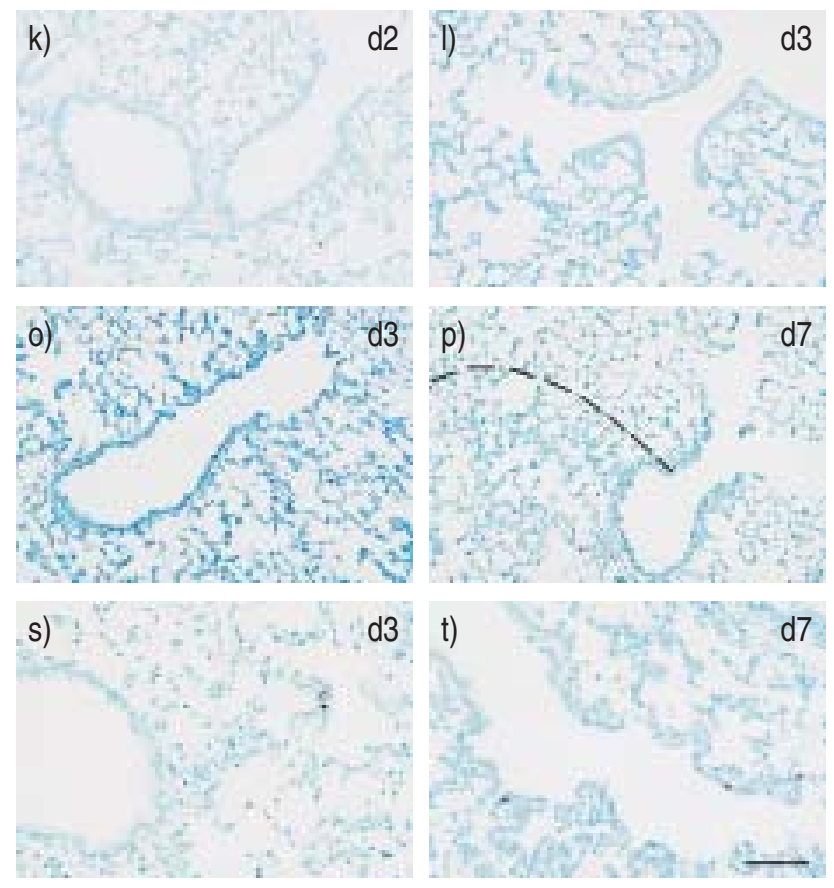

Fig. 1.-Indirect immunohistochemistry of distal airways of rat lung fixed at day 1, 2, 3 or 7 (d1, d2, d3 or d7) after instillation of recombinant human keratinocyte growth factor (KGF) (rHuKGF) (b-d, $\mathrm{f}-\mathrm{h}, \mathrm{j}-\mathrm{l})$ or adenoviral transfer of the human KGF gene (Ad5HuKGF). Distal bronchioles of untreated or PBS-treated animals are shown for comparison. Stainings for 5-bromo-2'-deoxyuridine $(\mathrm{BrdU})(\mathrm{a}-\mathrm{d})$, Clara cell specific protein $10(\mathrm{CC} 10)(\mathrm{e}-\mathrm{h}$ and $\mathrm{m}-\mathrm{p})$ and calcitonin gene-related peptide (CGRP) (i-l and $\mathrm{q}-\mathrm{t})$, respectively, were performed simultaneously for all sections of the complete time-series of both KGF and control lungs. Staining for BrdU reveals dramatic increase in proliferating cells at days 1 and 2, and return to control level by day 7 . Staining for CC10 was markedly reduced at days 1-3 in rHuKGF as well as in Ad5-HuKGF lungs. Reduction persisted near foci of alveolar epithelial cell proliferation (---) in Ad5HuKGF lungs at day 7 while it had completely returned to control levels in the rHuKGF animals. Staining for CGRP did not show any change in the number of CGRP-positive pulmonary neuroendocrine cells or in intensity of staining at any time point in any of the experiments. Scale bar $=100 \mu \mathrm{m}$.

(compare figs 3 and 4) whereas the levels of BrdU incorporation were higher at days 3 and 7 after gene transfer than after protein instillation. The fraction of airway epithelial surface covered by Ki67-positive cells peaked at day 2 after rHuKGF instillation and declined to control levels at day 7 (fig. 3). After gene transfer, Ki67 gradually declined and only reached control levels at day 21 (compare figs 3 and 4). While BrdU-incorporation was always markedly higher in lungs exposed to rHuKGF, individual lungs instilled with PBS also demonstrated considerable immunoreactivity for Ki67. Consequently, the difference between rHuKGF- and PBS-treated animals in the fraction of Ki67 immunoreactive cells did not reach statistical significance, which is in clear contrast to the fraction of BrdU-positive cells.

Clara cells and pulmonary neuroendocrine epithelial cells (PNEC) are potential airway epithelial progenitor cells, particularly in the distal bronchioles $[32,33]$. To identify which one of these potential progenitor cells responded to KGF-treatment in vivo, immunoreactivities for $\mathrm{CC} 10$ and calcitonin gene-related peptide (CGRP) (fig. 1), which are specific markers of Clara cells and PNECs, respectively, were examined. Further, double immunostainings were performed using antibodies against $\mathrm{CC} 10$ and $\mathrm{CGRP}$ in conjunction 

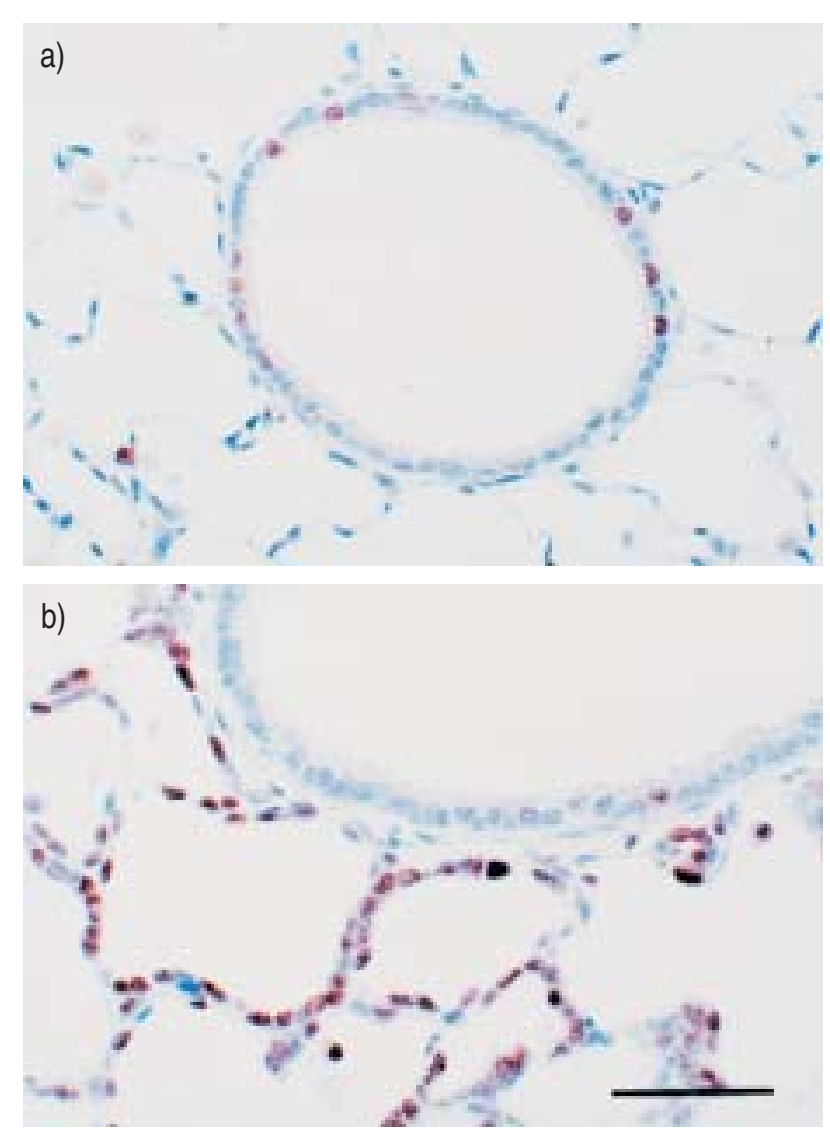

Fig. 2.-Indirect immunohistochemistry of distal airways of rat lung fixed at a) day 1 and b) day 3 after instillation of recombinant human keratinocyte growth factor (rHuKGF) demonstrating the expression of nuclear proliferation marker Ki67. Proliferation was prominent in distal bronchioles at day 1 when alveolar epithelial proliferation was low, while the opposite was true in lungs at day 3 after rHuKGF. Scale bar $=50 \mu \mathrm{m}$.

with staining for BrdU (figs 5 and 6). Using a monoclonal antibody to CGRP, no alterations in PNECs were observed throughout the experimental period (fig. 1). Since only a few PNECs were observed per section, the labelling index for BrdU was determined from double immunostainings (table 2). The authors observed that only three out of a total of 165 cell profiles of PNECs showed nuclear labelling for BrdU, observed in six lungs treated with rHuKGF-protein, while the total number of BrdUpositive cell profiles amounted to 4,085. In contrast, double immunostaining for BrdU and $\mathrm{CC} 10$ revealed that Clara cells constituted the majority of the proliferating population of distal airway cells following $\mathrm{rHuKGF}$ treatment in vivo (figs 5 and 6).

The phenotypic alterations associated with KGFinduced airway epithelial proliferation were defined based on changes in the immunoreactivity for $\mathrm{CC10}$ and SP-D, respectively (fig. 7), which are both well known secretary products of Clara cells [34]. There were also changes in the expression pattern of the membrane-bound adhesion molecule CD44v6, which has been implicated in cell-cell and cell-matrix interactions and airway epithelial repair [25, 26], and which is not expressed in cells of the neuroendocrine system [27]. Changes in CC10 and SP-D were estimated by means of stereology. The intensity of CC10 staining was considerably decreased after human KGFtreatment $(\mathrm{p}=0.001)$, whereas SP-D staining increased $(\mathrm{p}<0.001)$, as judged by estimating the airway surface fraction covered by CC10- and SP-D-positive cells, respectively (fig. 3). Notably, the alterations in CC10immunoreactivity were confined to a subpopulation of Clara cells that exhibited very weak staining, which was frequently restricted to the apical portion of the cytoplasm (fig. 7). Until day 3 after instillation with rHuKGF, the fraction of these weakly staining cells increased (fig. 3d) at the expense of Clara cells that strongly stained for $\mathrm{CC10}$ (fig. 3c). These alterations were highly significant in comparison to PBS-instilled lungs.

The immunoreactivity for CD44v6 was markedly increased in lungs that received $\mathrm{rHuKGF}$-protein instillation or human KGF-gene transfer (fig. 7). The alteration in cell shape from a cuboidal to a slightly columnar bronchiolar epithelium was particularly apparent as expression of CD44v6 increased at the lateral cell membranes. This effect was already seen at day 1 after instillation of human KGF protein. It was most prominent at days 2 and 3 after rHuKGF instillation, and persisted up to day 14 in lungs subjected to human KGF gene transfer. Again, the alterations of the airway epithelium had resolved at day 7 after rHuKGF-instillation and by day 21 after gene transfer. There was no effect on airway brush and alveolar epithelial type III cells identified by a monoclonal antibody against cytokeratin 18 (not shown).

In previous studies, the current authors have shown that apoptosis was involved in the resolution of alveolar epithelial hyperplasia [7]. To address whether this was also true for the resolution of airway epithelial cell proliferation, double staining with an anti-cytokeratin antibody (MNF-116), a marker of epithelial cells, was performed in combination with the TUNEL assay [31]. However, only single apoptotic airway epithelial cells were seen in human KGFtreated lungs (fig. 8). Occasionally, macrophages containing apoptotic bodies were seen in the subepithelial interstitial tissue. However, there was no sign of an increased incidence of apoptotic airway epithelial cells in comparison with untreated lungs or lungs that had received PBS.

\section{Discussion}

This study investigated the in vivo response of the airway epithelium to a potent epithelial mitogen, $\mathrm{KGF}$. The effect of KGF was examined in two in vivo rat models, i.e. endobronchial instillation of the recombinant human KGF-protein [13] and Ad5-HuKGF gene transfer [30], respectively. It has been demonstrated, by quantitative stereology in conjunction with immunohistochemistry, that either treatment resulted in transient proliferation as well as transient phenotypic alterations of the airway epithelium. By means of double immunolabelling experiments, only one cell type of the distal airway epithelium was shown to proliferate in response to $\mathrm{KGF}$, the Clara cell. 

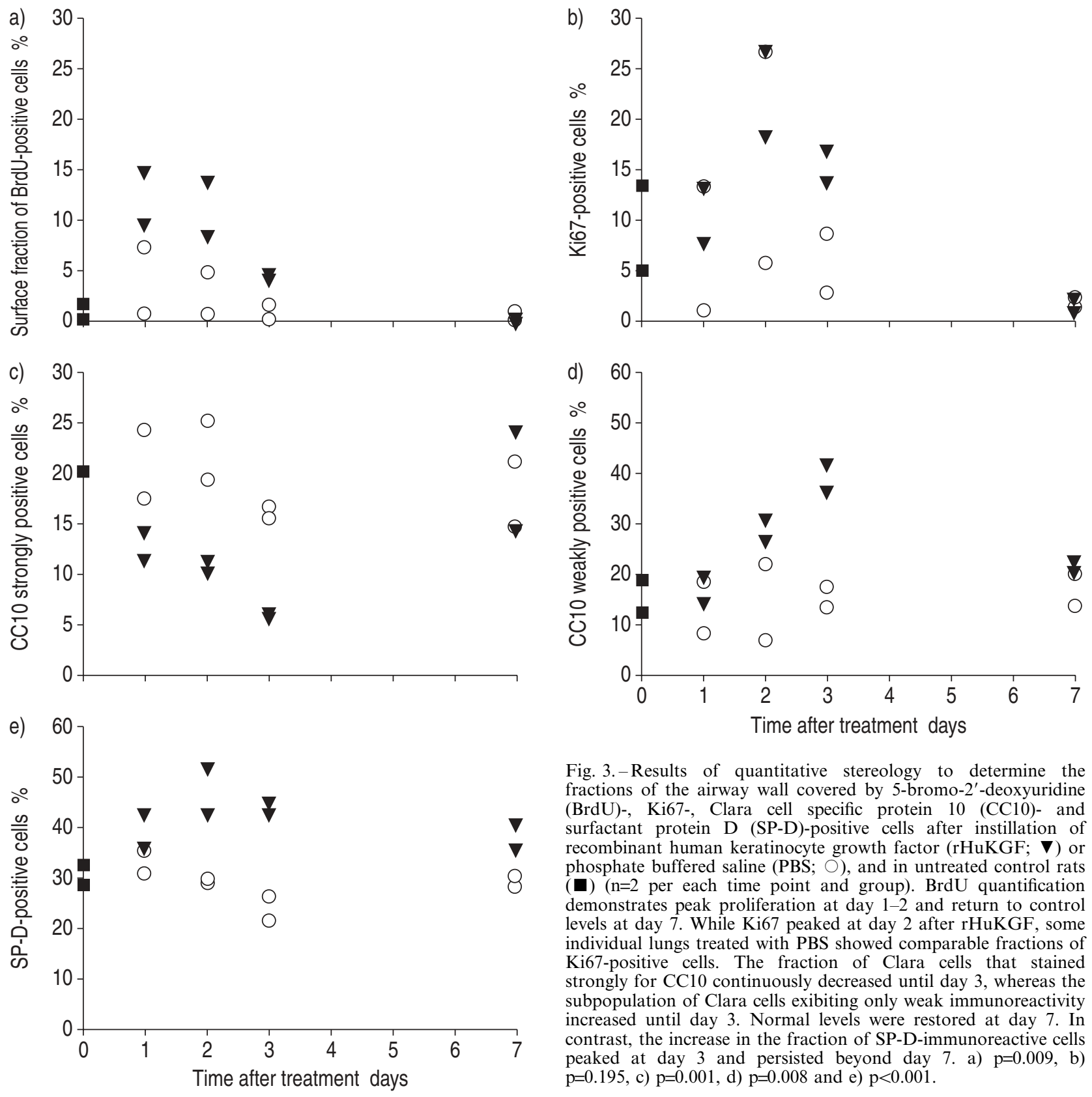

Fig. 3.-Results of quantitative stereology to determine the fractions of the airway wall covered by 5-bromo-2'-deoxyuridine (BrdU)-, Ki67-, Clara cell specific protein 10 (CC10)- and surfactant protein D (SP-D)-positive cells after instillation of recombinant human keratinocyte growth factor (rHuKGF; $\boldsymbol{\nabla}$ ) or phosphate buffered saline (PBS; O), and in untreated control rats

(ם) ( $\mathrm{n}=2$ per each time point and group). BrdU quantification demonstrates peak proliferation at day $1-2$ and return to control levels at day 7. While Ki67 peaked at day 2 after rHuKGF, some individual lungs treated with PBS showed comparable fractions of Ki67-positive cells. The fraction of Clara cells that stained strongly for CC10 continuously decreased until day 3 , whereas the subpopulation of Clara cells exibiting only weak immunoreactivity increased until day 3. Normal levels were restored at day 7. In contrast, the increase in the fraction of SP-D-immunoreactive cells peaked at day 3 and persisted beyond day 7. a) $p=0.009$, b) $\mathrm{p}=0.195, \mathrm{c}) \mathrm{p}=0.001, \mathrm{~d}) \mathrm{p}=0.008$ and e) $\mathrm{p}<0.001$.

Although previous studies have demonstrated that $\mathrm{KGF}$ is a mitogen of airway epithelial cells in vitro and in vivo [5, 6, 8, 21-23], nothing was known about the precise type of cell that responded to human KGF. In this study, it has been established by means of double immunofluorescence staining, that Clara cells are the major cell type of the bronchiolar epithelium that proliferate in response to human KGF-treatment. There were no signs of any significant proliferation of PNECs, another potential progenitor cell type of the airway epithelium, particularly in response to largescale Clara cell loss [33, 35].

Although PNECs constitute a very small cell population of the airways and are characterised by a low rate of proliferation [36], PNECs may proliferate

considerably under certain conditions. Experimentally induced hyperplasia of PNECs has been observed to occur in response to various toxic gases or carcinogenic stimuli [37]. Depending on the specific stimulus, the proliferative effect may be specifically restricted to a certain airway region [38, 39]. PNEC proliferation was also seen in a number of non-neoplastic human lung diseases [37]. A marked increase in the number of PNECs was observed in neonatal bronchopulmonary dysplasia [40] as well as in human neonates with congenital diaphragmatic hernia $(\mathrm{CDH})$ [41]. In an experimental model of $\mathrm{CDH}$, lung malformation and its rescue was reported to be associated with decreased levels of KGF protein and messenger ribonucleic acid (mRNA) [42]. This is corroborated by studies 

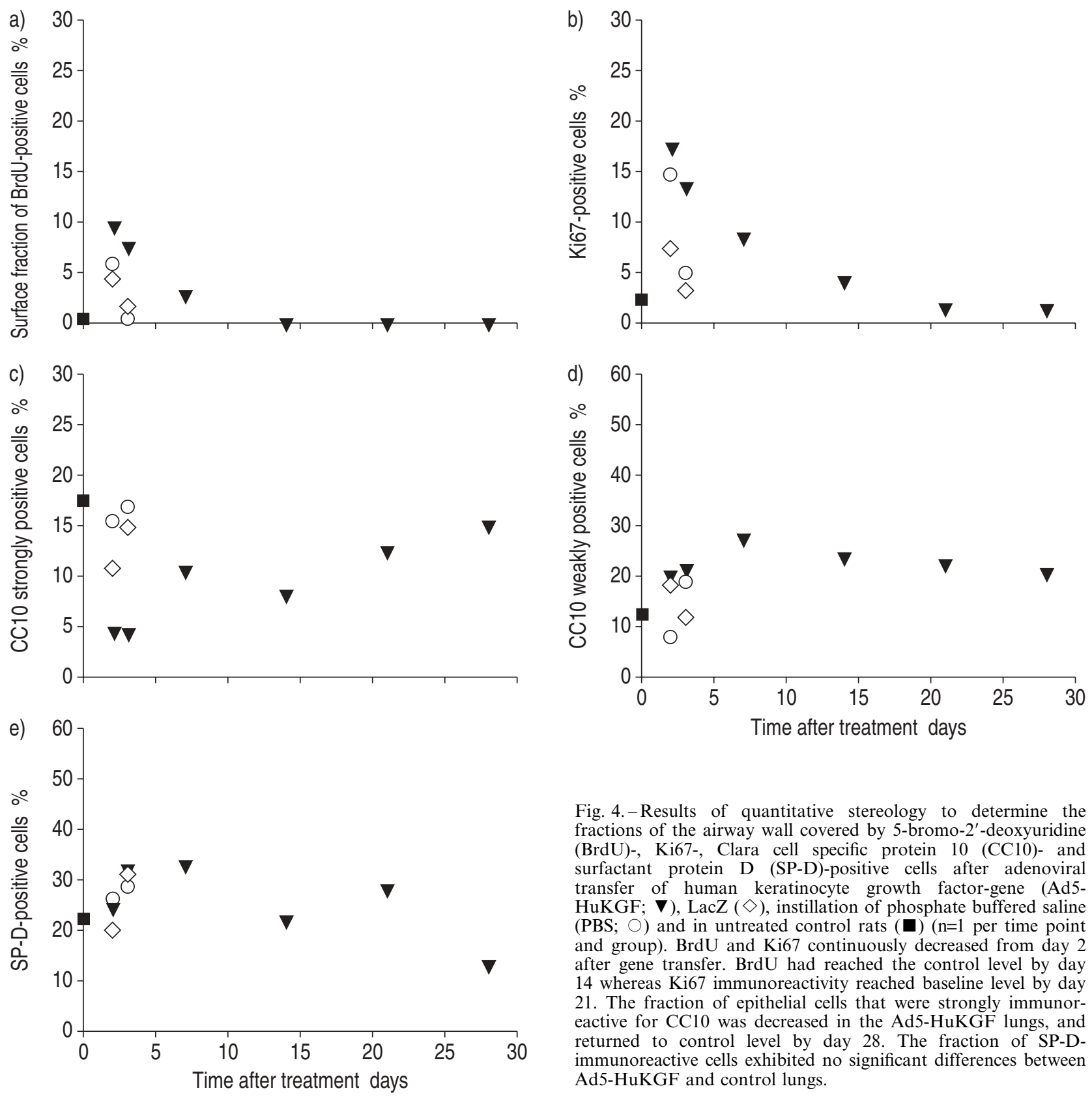

Fig. 4.-Results of quantitative stereology to determine the fractions of the airway wall covered by 5-bromo-2'-deoxyuridine (BrdU)-, Ki67-, Clara cell specific protein 10 (CC10)- and surfactant protein D (SP-D)-positive cells after adenoviral transfer of human keratinocyte growth factor-gene (Ad5HuKGF; $\boldsymbol{\nabla})$, LacZ $(\diamond)$, instillation of phosphate buffered saline (PBS; $\bigcirc)$ and in untreated control rats $(\mathbf{\square})(n=1$ per time point and group). BrdU and Ki67 continuously decreased from day 2 after gene transfer. BrdU had reached the control level by day 14 whereas Ki67 immunoreactivity reached baseline level by day 21 . The fraction of epithelial cells that were strongly immunoreactive for $\mathrm{CC} 10$ was decreased in the Ad5-HuKGF lungs, and returned to control level by day 28. The fraction of SP-Dimmunoreactive cells exhibited no significant differences between Ad5-HuKGF and control lungs.

performed in foetal mouse lung explants, which indicated that incubation with rHuKGF inhibits rather thanstimulates the proliferation of PNECs [37].

Hong et al. [43] demonstrated, in a very elegant transgenic approach, that when Clara cells were ablated, CGRP-immunoreactive PNECs were unable to repopulate the Clara cell-depleted distal airways. In addition, BORTHWICK et al. [44] reported that the potential stem cell population of the trachea, which was identified as BrdU label-retaining cells after oxygen saturation-induced injury, did not express the PNEC marker CGRP [44]. As most neuroendocrine tumours and the cells of the neuroendocrine system do not express CD44v6 [27], the increased expression of this membrane-bound adhesion molecule in

response to rHuKGF further indicates that the responsive cells are not PNECs.

The proliferative potential of airway progenitor cells may depend on at least two factors not addressed in many of the previous studies: 1) the airway level examined and 2) the extent of injury produced. The pattern of epithelial repair was shown to vary widely depending on the degree of injury to the airways [45, 46]. In the current study, airway level was carefully defined to include terminal bronchioles, the last conducting airway before the gas exchange region, and the extent of injury is not an issue here as human KGF was administered to cells in steady state.

As expected, the kinetics of cell proliferative and phenotypic changes differed between protein 

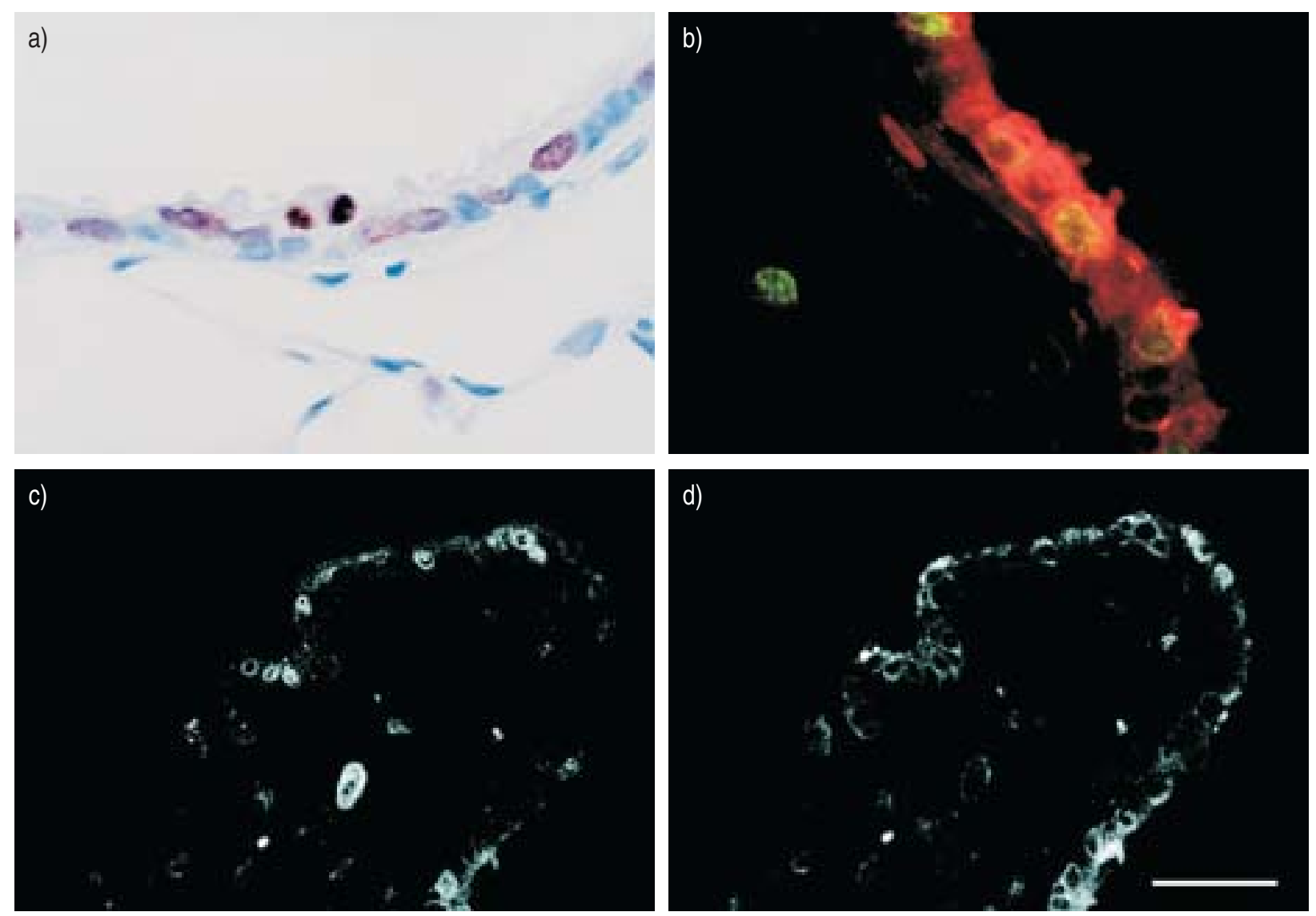

Fig. 5. - a) Indirect immunohistochemistry and b-d) immunofluorescence staining of distal airways of rat lungs fixed at day 1 after instillation of recombinant human keratinocyte growth factor (rHuKGF). a) Expression of nuclear proliferation marker Ki67 (brown) in a Clara cell caught during cell division. b) Double immunofluorescence staining for Clara cell specific protein 10 (CC10; red) and 5-bromo-2'-deoxyuridine (BrdU; green) demonstrates that BrdU-positive nuclei were confined to CC10-immunoreactive cells only. The overview at lower magnification confirms that c) immunofluorescence staining for BrdU (bright nuclei) colocalises with d) cytoplasmic staining for $\mathrm{CC} 10$ in bronchiolar epithelial cells. This indicates that Clara cells represent at least the major component of population of proliferating airway epithelial cells. a) and b) Scale bar=50 $\mu \mathrm{m}$; c) and d) scale bar=100 $\mu \mathrm{m}$.

instillation and gene transfer in bronchiolar versus alveolar epithelial cells. Airway epithelial proliferation, assessed by immunohistochemistry for Ki67 as well as for BrdU, reached highest levels at day 1-2 after both types of KGF treatment. Thus, proliferation of Clara cells peaked at a slightly earlier timepoint than the proliferation of alveolar epithelial type II cells (day 2-3) reported in previous studies [5, 7, 21, 47]. This was even true for proliferation of the airway epithelium after adenoviral KGF gene transfer, where hyperplasia of type II cells also peaked at day 2-3 [30] (unpublished data). These data indicate that Clara cells may act more rapidly upon stimulation of repair mechanisms than alveolar epithelial type II cells.

Airway epithelial proliferation returned to control levels by day 7 after instillation of rHuKGF protein and by day 21 after gene transfer, respectively. This compares well with the kinetics of restoration of the alveolar epithelium, which exhibited normal architecture after about 7 days following protein instillation [5, 7] and by day 21 following gene transfer [30] (unpublished data). Similarly, the marked airway epithelial hyperplasia seen in transgenic mice that conditionally express human KGF, under the control of the $\mathrm{CC} 10$ promoter during doxycycline adminis- tration, was reduced 7 days after cessation of doxycycline and was largely resolved after 14 days [8]. It was found that 7 days after adenoviral transfer of the human KGF, airway epithelial proliferation was restricted to areas near foci of alveolar epithelial proliferation, which according to in situ hybridisation studies were most likely the result of KGF derived from solitary type II cells that express human KGF [30], and was completely resolved by day 21 . Notably, KGF appeared to act in a negative feedback loop on the expression of its own receptor, which was downregulated at the transcription level by 2.3 -fold in primary cultures of human airway epithelial cells exposed for $20 \mathrm{~h}$ to $50 \mathrm{ng} \mathrm{KGF} \cdot \mathrm{mL}^{-1}$ [28]. This may indicate that cells already stimulated by KGF may exhibit a weaker response to a second KGF stimulus.

Individual lungs instilled with PBS exhibited considerable immunoreactivity for $\mathrm{Ki67}$, whereas BrdU incorporation was consistently higher in lungs exposed to rHuKGF. This finding indicates that the use of $\mathrm{Ki67}$ as a proliferation marker may bear some inherent problem rather than that PBS is a mitogen of airway epithelial cells. A major problem in determining the proliferative or growth fraction of a given tissue is the definition of the nonproliferative 

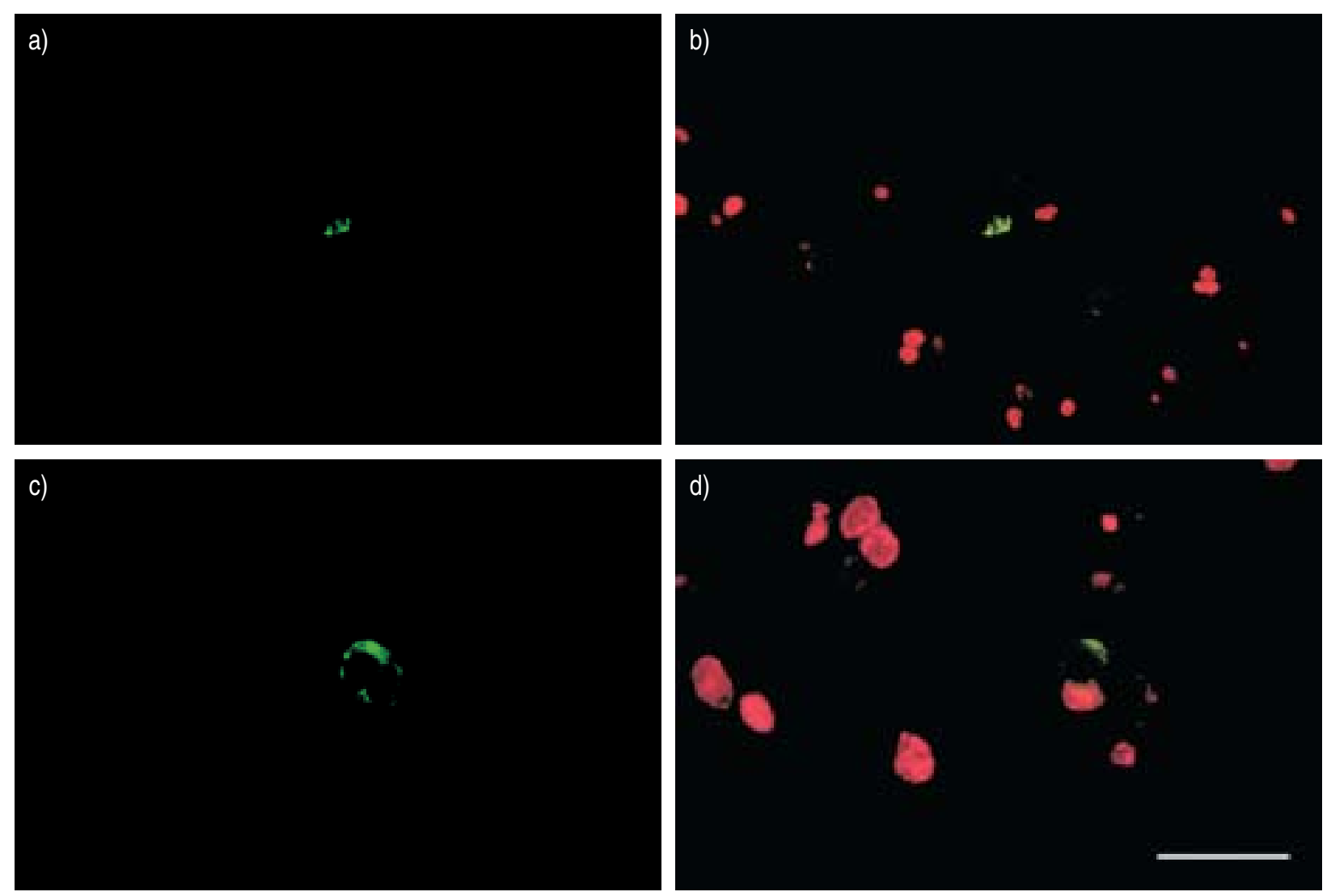

Fig. 6. - Indirect immunofluorescence staining of distal airways of rat lungs fixed at day 1 ( $a$ and $b$ ) and day 3 (c and d) after instillation of recombinant human keratinocyte growth factor (rHuKGF). Small groups of pulmonary neuroendocrine cells (PNECs) were revealed by anti-calcitonin gene-related peptide (CGRP; green) staining (a and c). Double staining for CGRP and 5-bromo-2'-deoxyuridine (BrdU; red) (b and d) revealed that these cells did not incorporate BrdU, whereas many surrounding airway as well as alveolar epithelial cells did. This indicates that PNECs did not contribute to the population of proliferating airway epithelial cells. Scale bar=100 $\mu \mathrm{m}$.

state. Different techniques have been developed to assess cell proliferation [48]. Standard procedures to determine the growth fraction are generally based on experimental protocols in which newly synthesised

Table 2. - Summary of double immunolabelling to detect proliferating neuroendocrine airway epithelial cell profiles in individual animals after instillation of recombinant human keratinocyte growth factor protein into rat lungs in vivo

\begin{tabular}{lcccc}
\hline $\begin{array}{l}\text { Animal } \\
\text { no. }\end{array}$ & $\begin{array}{c}\text { Time } \\
\text { days }\end{array}$ & $\begin{array}{c}\mathrm{BrdU}^{+} \\
\mathrm{CGRP}^{+}\end{array}$ & $\begin{array}{c}\mathrm{BrdU}^{-} \\
\mathrm{CGRP}^{+}\end{array}$ & $\begin{array}{c}\mathrm{BrdU}^{+} \\
\mathrm{CGRP}^{-}\end{array}$ \\
\hline 1 & 0 & 0 & 20 & 57 \\
2 & 1 & 0 & 28 & 879 \\
3 & 1 & 0 & 42 & 2003 \\
4 & 2 & 0 & 7 & 466 \\
5 & 2 & 0 & 3 & 194 \\
6 & 3 & 0 & 9 & 212 \\
7 & 3 & 3 & 53 & 328 \\
Total & & 3 & 162 & 4139 \\
\hline
\end{tabular}

Each row denotes the number of cell profiles detected in individual animals by double immunofluorescence labelling for 5-bromo-2'-deoxyuridine (BrdU), which was given by intraperitoneal injection $4 \mathrm{~h}$ before sacrifice and which was incorporated by proliferating cells during S-phase, and/or for the neuroendocrine cell marker, calcitonin gene-related peptide (CGRP), respectively. deoxyribonucleic acid (DNA) is labelled during the $\mathrm{S}$ phase, e.g. by offering BrdU to be incorporated into newly synthesised DNA. As has been pointed out by others [49-51], this approach may underestimate the growth fraction of cells. On the contrary, the nuclear protein $\mathrm{Ki} 67$ that is expressed throughout all phases of the cell cycle, i.e. from early $\mathrm{G} 1$ through $\mathrm{S}, \mathrm{G} 2$, and $\mathrm{M}$, labels all cells that have entered the cell cycle [51]. Because only cells in G0 are devoid of $\mathrm{Ki67}$, this approach, however, may overestimate the growth fraction because all cells are labelled that have the potential to divide. In turn, these cells also have the choice to leave the cell cycle and become quiescent or terminally differentiated. Immunoreactivity for Ki-67 does not necessarily mean that a cell is unquestionably going to divide [51]. The current data clearly indicate that $\mathrm{rHuKGF}$ induces airway epithelial cell division in the rat, as was demonstrated by the significant increase in cells that incorporated BrdU. On the contrary, the instillation of PBS alone may stimulate airway epithelial cells to enter the cell cycle (as evidenced by the immunoreactivity for Ki67), while additional events will be necessary to drive the cells towards mitosis. Therefore, Ki67 may not be the optimal choice to assess the mitotic activity of the airway epithelium in experiments that involve the instillation of fluid via the trachea.

The effect of human KGF on the airway epithelium 

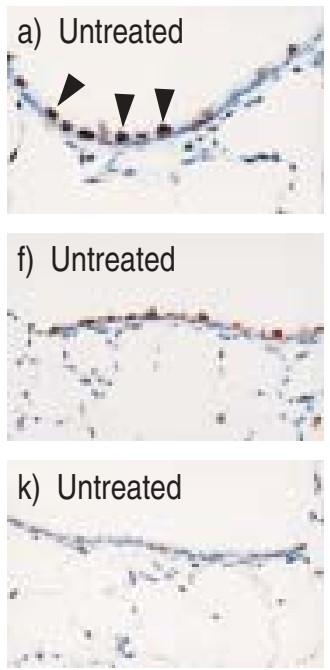
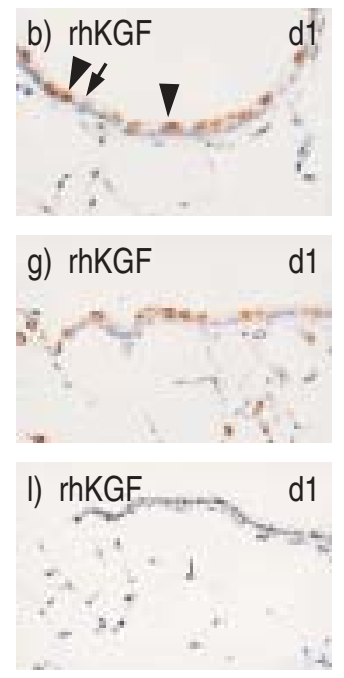
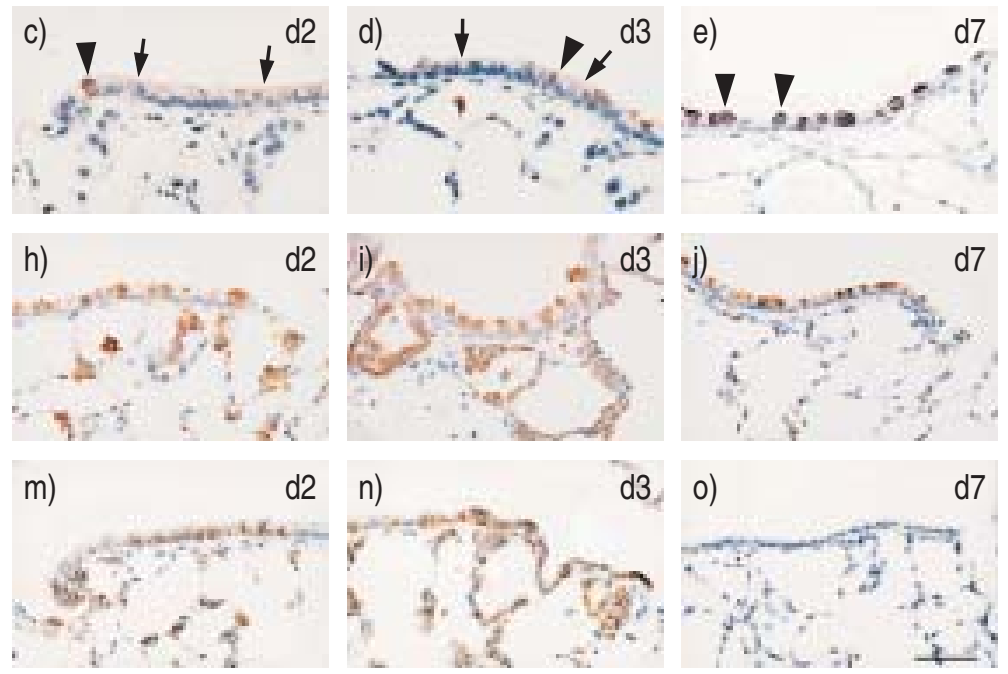

Fig. 7.-Indirect immunohistochemistry of distal airways of rat lung fixed at day 1, 2, 3, and 7 (d1, d2, d3 or d7) after instillation of recombinant human keratinocyte growth factor (KGF) (rHuKGF). Distal bronchioles of untreated animals are shown for comparison. Stainings for Clara cell specific protein $10(\mathrm{CC10})(\mathrm{a}-\mathrm{e})$, surfactant protein D (SP-D) (f-j) and CD44v6 (k-o), respectively, were performed simultaneously for all sections of the complete time-series of both rHuKGF and control lungs. From day 1-3, there was a marked shift from the subpopulation of Clara cells that stain strongly for CC10 (arrowheads) towards a subpopulation of Clara cells exhibiting only very weak immunoreactivity for CC10 (arrows). This was paralleled by a slight increase in SP-D-staining, and a dramatic increase in the membrane-bound adhesion molecule CD44v6, which was accompanied by a transition from a cuboidal to a slightly columnar epithelium. All these phenotypic changes were returned to control levels by day 7 . Scale bar $=100 \mu \mathrm{m}$.

was not limited to proliferation but included profound phenotypic alterations, which were the same irrespective of the mode of human KGF delivery to lung, i.e. protein instillation or gene transfer. The changes were most readily seen in the distal airways and were also transient. The bronchiolar epithelial cells, which are characterised by low cuboidal shape in control lungs, exhibited a more cylindrical shape after human KGFtreatment. The altered morphological appearance was accompanied by a marked increase in the expression of the membrane-bound adhesion molecule CD44v6 at the lateral cell membrane, an increase in cytoplasmic immunoreactive SP-D and a decreased cytoplasmic expression of immunoreactive $\mathrm{CC} 10$. While CD44v6 and CC10 reached control levels at day 7 after instillation of $\mathrm{rHuKGF}$ protein, the fraction of airway epithelial cells that stained for SP-D was still above control level. These data extend previous findings that the bronchiolar epithelium responded with an increase in SP-D, a transient decrease in CC10 after instillation of $\mathrm{KGF}$ protein in vivo, both at the level of protein and mRNA, whereas SP-A appeared unchanged [21]. The data of YANO et al. [21] rely on the analysis of whole lung homogenates. Looking at alveolar type II cells isolated from KGF-treated lungs, however, the same study demonstrated that the levels of SP-D mRNA were decreased on a per cell basis [21]. As appropriate techniques to isolate Clara cells at a sufficiently high purity and cell number are still lacking, quantitative morphometric labelling experiments are the only approach by which cell type-specific changes can be monitored. Using this approach, the current authors have demonstrated a shift from Clara cells that exhibit strong cytoplasmic immunoreactivity for CC10 to Clara cells that exhibit only very weak apical labelling for CC10. In addition, they have demonstrated that the fraction of cells which are strongly immunoreactive for $\mathrm{CC} 10$ decreased while weakly staining cells increased after gene transfer. Hence, these data suggest that the expression of $\mathrm{CC} 10$ is not homogeneously reduced in all Clara cells at a time whereas there is not a decrease but an increase in immunostaining for SP-D, which is a more uniform effect. In contrast, however, CC10 immunoreactivity appeared normal in transgenic mice that over express KGF after doxycycline administration [8].

Until now, the functional consequences of these alterations induced by human KGF were not known. CC10-knockout mice exhibited an increased susceptibility to inhaled oxidant gases [52]. SINGH and KATYAL [34] suggested that $\mathrm{CC10}$ may function as a regulator of inflammation in the lung, a notion which is still a matter of debate [28, 52-55]. CC10 was reported to be decreased in various conditions of inflammation [53, 56, 57], and deficiency in $\mathrm{CC} 10$ as a result of transgenic experiments or in humans with a chronic CC10 deficiency, e.g. in long-term cigarette smokers $[58,59]$, appears to be characterised by a tendency towards an exaggerated inflammatory response [53, 55], and may contribute to carcinogenesis [59]. The potential of recombinant human CC10 as a therapeutic for inflammatory and fibrotic diseases is currently under investigation [55].

While in control rat lungs weak immunoreactivity for CD44v6 was observed in only a few airway epithelial cells, including bronchiolar Clara cells, CD44v6 was markedly increased after human KGF treatment. Notably, CD44v6 was markedly increased in human bronchial epithelial cell lines after mechanical damage in an in vitro model of repair [26]. As CD44v6 was also seen to be markedly increased in hyperplastic alveolar epithelial type II cells after instillation of $\mathrm{rHuKGF}$ 

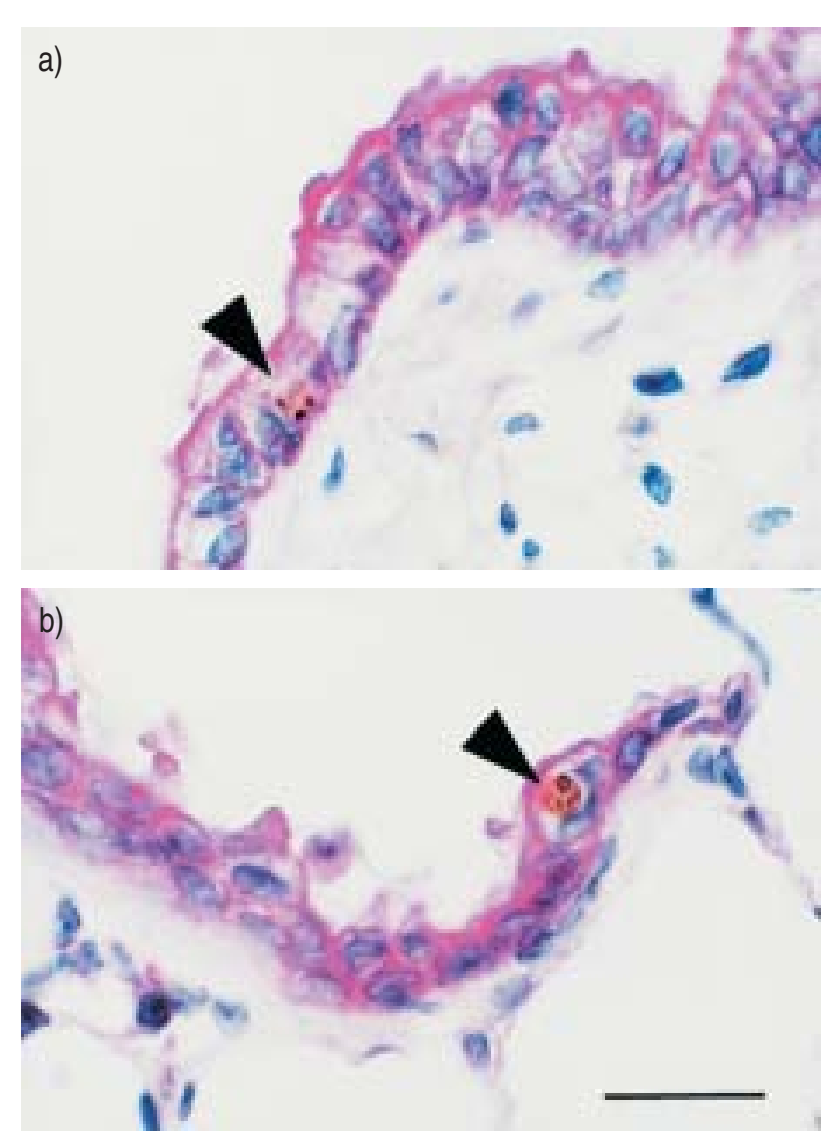

Fig. 8.-Double staining by terminal deoxynucleotidyl transferasemediated deoxyuridine triphosphate nick end-labelling (TUNEL) assay (brown) and indirect immunophosphatase (APAAP) staining (pink) using the monoclonal antibody MNF116, an anticytokeratin antibody which stains epithelial cells only. TUNELpositive apoptotic airway epithelial cells (arrowheads) are rarely seen after recombinant human keratinocyte growth factorinstillation at a) day 3 and b) day 7 whereas apoptosis of alveolar epithelial type II cells was frequently seen as reported previously $[7,31]$. Scale bar $=50 \mu \mathrm{m}$.

and was observed at the lateral membranes of type II/ type I cell intermediates [7], the increase in CD44v6 most likely mirrors its functional involvement in cell migration, differentiation and/or altered cell-substrate adhesion in epithelial repair, as was also indicated by other studies $[22,26]$. In turn, loss of CD44v6 may result in detachment from the extracellular matrix with subsequent apoptosis [60].

The orchestration of the sequence of processes defined as "repair", which includes proliferation, migration, differentiation and death of airway epithelial cells, is necessary to reconstitute the normal architecture of the airway epithelium after acute injury $[46,61]$. In turn, chronic lung diseases like asthma or chronic obstructive pulmonary disease are characterised, among other features, by profound alterations of the airway epithelial architecture resulting in a "remodelled" airway wall [62]. The process of airway wall remodelling has been attributed to the combination of chronic repetitive injury on one hand and the ensuing repair process on the other. For example, exposure to environmental cigarette smoke prior to lung injury resulted in a delay in bronchiolar repair in mice [63].
As was comprehensively reviewed recently by WARE and Matthay [2], KGF has impressive protective effects against a wide variety of injurious stimuli when given as a pre-treatment in animal models. Various mechanisms are thought to contribute to this protective effect including enhancement of alveolar repair and inhibition of alveolar epithelial cell apoptosis [16-18, 64], and upregulation of alveolar epithelial ion and fluid transport $[14,65]$, which may be particularly important in acute lung injury models. KGF enhanced active ion transport across monolayers of isolated rat alveolar epithelial type II cells, primarily due to increased expression of $\mathrm{Na}^{+}-\mathrm{K}^{+}$-adenosine triphosphatase $\alpha_{1}$-subunit [14]. In the normal rat lung in vivo, intratracheal pre-treatment with $\mathrm{KGF}$ was reported to increase alveolar epithelial fluid transport primarily by its mitogenic effect on alveolar epithelial type II cells [65]. Since Clara cells were reported to be involved in regulated ion and fluid transport in the distal airways [66, 67], future studies will be welcome that investigate the potential linkage between the induction of mitosis in Clara cells by KGF, as shown in the present study, and bronchiolar ion and fluid transport to reveal any airway-related contribution to the protective effect of KGF against pulmonary oedema in acute lung injury.

In this study, the effects observed were a result of the administration of KGF along the airway route. It would be interesting to learn from future studies if intravenous application of KGF induces similar changes in proliferation and phenotype of airway epithelial cells. Guo et al. [47] reported that intravenous administration of rHuKGF resulted in an equivalent proliferative response of rat airway epithelium as compared with intratracheal instillation, whereas the response of alveolar epithelial type II cells to intravenous administration was markedly lower. Notably, the same study reported correspondingly low responses of both alveolar and bronchial epithelium after intravenous versus intratracheal administration in mice.

In conclusion, the great potential of human keratinocyte growth factor to protect the lung against various injuries may not only rely on its effects on the alveolar epithelium but is likely to include its ability to stimulate processes implicated in airway epithelial repair, e.g. proliferation of Clara cells and increased expression of epithelial CD44v6. The contribution of other effects, e.g. on airway ion and fluid transport, awaits further elucidation.

\footnotetext{
Acknowledgements. rHuKGF was a generous gift from T. Ulich (Amgen Inc., Thousand Oaks, CA, USA). The polyclonal antiserum against $\mathrm{CC} 10$ was a generous gift of $\mathrm{J}$. Klug (Philipps-University, Marburg, Germany). The expert technical assistance of R. Pohlers, I. Peterson and S. Langer in immunohistochemical and immunofluorescence staining; of $\mathrm{B}$. Kettner and B. Liebscher in electron microscopy; and of H. Seidel and M. Glauche (Technical University of Dresden, Dresden, Germany) for photographic reproduction and digital artwork is acknowledged with thanks. The authors cordially thank L. van Winkle
} 
(UC Davis, CA, USA) for her critical comments on a draft of this paper.

\section{References}

1. Rubin JS, Bottaro DP, Chedid M, et al. Keratinocyte growth factor. Cell Biol Int 1995; 19: 399-411.

2. Ware LB, Matthay MA. Keratinocyte and hepatocyte growth factors in the lung: roles in lung development, inflammation, and repair. Am J Physiol 2002; 282: L924-L940.

3. Panos RJ, Rubin JS, Csaky KG, Aaronson SA, Mason RJ. Keratinocyte growth factor and hepatocyte growth factor/scatter factor are heparin-binding growth factors for alveolar type II cells in fibroblastconditioned medium. J Clin Invest 1993; 92: 969-977.

4. Sugahara K, Rubin JS, Mason RJ, Aronsen EL, Shannon JM. Keratinocyte growth factor increases mRNAs for SP-A and SP-B in adult rat alveolar type II cells in culture. Am J Physiol 1995; 269: L344-L350.

5. Ulich TR, Yi ES, Longmuir K, et al. Keratinocyte growth factor is a growth factor for type II pneumocytes in vivo. J Clin Invest 1994; 93: 562-572.

6. Panos RJ, Bak PM, Simonet WS, Rubin JS, Smith LJ. Intratracheal instillation of keratinocyte growth factor decreases hyperoxia-induced mortality in rats. $J$ Clin Invest 1995; 96: 2026-2033.

7. Fehrenbach H, Kasper M, Tschernig T, et al. Keratinocyte growth factor-induced hyperplasia of rat alveolar type II cells in vivo is resolved by differentiation into type I cells and by apoptosis. Eur Respir $J$ 1999; 14: 534-544.

8. Tichelaar JW, Lu W, Whitsett JA. Conditional expression of fibroblast growth factor-7 in the developing and mature lung. $J$ Biol Chem 2000; 275: 11858-11864.

9. Yano T, Deterding RR, Simonet WS, Shannon JM, Mason RJ. Keratinocyte growth factor reduces lung damage due to acid instillation in rats. Am J Respir Cell Mol Biol 1996; 15: 433-442.

10. Mason CM, Guery BP, Summer WR, Nelson S. Keratinocyte growth factor attenuates lung leak induced by alpha-naphthylthiourea in rats. Crit Care Med 1996; 24: 925-931.

11. Barazzone C, Donati YR, Rochat AF, et al. Keratinocyte growth factor protects alveolar epithelium and endothelium from oxygen-induced injury in mice. $\mathrm{Am}$ J Pathol 1999; 154: 1479-1487.

12. Welsh DA, Guery BP, Deboisblanc BP, et al. Keratinocyte growth factor attenuates hydrostatic pulmonary edema in an isolated, perfused rat lung model. Am J Physiol 2001; 280: H1311-1317.

13. Deterding RR, Havill AM, Yano T, et al. Prevention of bleomycin-induced lung injury in rats by keratinocyte growth factor. Proc Assoc Am Physicians 1997; 109: 254-268.

14. Borok Z, Danto SI, Dimen LL, Zhang XL, Lubman RL. $\mathrm{Na}^{+}-\mathrm{K}^{+}$-ATPase expression in alveolar epithelial cells: upregulation of active ion transport by KGF. Am J Physiol 1998; 274: L149-L158.

15. Wang Y, Folkesson HG, Jayr C, Ware LB, Matthay MA. Alveolar epithelial fluid transport can be simultaneously upregulated by both KGF and betaagonist therapy. J Appl Physiol 1999; 87: 1852-1860.

16. Buckley S, Barsky L, Driscoll B, Weinberg K, Anderson KD, Warburton D. Apoptosis and DNA damage in type 2 alveolar epithelial cells cultured from hyperoxic rats. Am J Physiol 1998; 274: L714-L720.

17. Panoskaltsis-Mortari A, Ingbar DH, Jung $\mathrm{P}$, et al. KGF pretreatment decreases B7 and granzyme B expression and hastens repair in lungs of mice after allogeneic BMT. Am J Physiol 2000; 278: L988-L999.

18. Kasper M, Roehlecke C, Witt M, et al. Induction of apoptosis by glyoxal in human embryonic lung epithelial cell line L132. Am J Respir Cell Mol Biol 2000; 23: 485-491.

19. Waters CM, Savla U, Panos RJ. KGF prevents hydrogen peroxide-induced increases in airway epithelial cell permeability. Am J Physiol 1997; 272: L681L689.

20. Savla U, Waters CM. Barrier function of airway epithelium: effects of radiation and protection by keratinocyte growth factor. Radiat Res 1998; 150: 195-203.

21. Yano T, Mason RJ, Pan T, Deterding RR, Nielsen LD, Shannon JM. KGF regulates pulmonary epithelial proliferation and surfactant protein gene expression in adult rat lung. Am J Physiol 2000; 279: L1146-L1158.

22. Waters CM, Savla U. Keratinocyte growth factor accelerates wound closure in airway epithelium during cyclic mechanical strain. J Cell Physiol 1999; 181: 424 432.

23. Michelson PH, Tigue $\mathrm{M}$, Panos RJ, Sporn PH. Keratinocyte growth factor stimulates bronchial epithelial cell proliferation in vitro and in vivo. Am J Physiol 1999; 277: L737-L742.

24. Shiratori M, Oshika E, Ung LP, et al. Keratinocyte growth factor and embryonic rat lung morphogenesis. Am J Respir Cell Mol Biol 1996; 15: 328-338.

25. Kasper M, Günthert U, Dall $\mathrm{P}$, et al. Distinct expression patterns of CD44 isoforms during human lung development and in pulmonary fibrosis. $\mathrm{Am}$ J Respir Cell Mol Biol 1995; 13: 648-656.

26. Leir SH, Baker JE, Holgate ST, Lackie PM. Increased CD44 expression in human bronchial epithelial repair after damage or plating at low cell densities. Am J Physiol 2000; 278: L1129-L1137.

27. Fasano M, Sabatini MT, Wieczorek R, Sidhu G, Goswami S, Jagirdar J. CD44 and its v6 spliced variant in lung tumors: a role in histogenesis? Cancer 1997; 80: 34 41.

28. Prince LS, Karp PH, Moninger TO, Welsh MJ. KGF alters gene expression in human airway epithelia: potential regulation of the inflammatory response. Physiol Genomics 2001; 6: 81-89.

29. Plopper CG, Hyde DM. Epithelial cells of bronchioles. In: Parent RA, ed. Comparative Biology of the Normal Lung. Boca Raton, CRC Press, 1992; pp. 85-92.

30. Morikawa O, Walker TA, Nielsen LD, Pan T, Cook JL, Mason RJ. Effect of adenovector-mediated gene transfer of keratinocyte growth factor on the proliferation of alveolar type II cells in vitro and in vivo. Am J Respir Cell Mol Biol 2000; 23: 626-635.

31. Fehrenbach H, Kasper M, Koslowski R, et al. Alveolar epithelial type II cell apoptosis in vivo during resolution of keratinocyte growth factor-induced hyperplasia in the rat. Histochem Cell Biol 2000; 114: 49-61.

32. Plopper CG, Nishio SJ, Alley JL, Kass P, Hyde DM. The role of the nonciliated bronchiolar epithelial (Clara) cell as the progenitor cell during bronchiolar epithelial differentiation in the perinatal rabbit lung. Am J Respir Cell Mol Biol 1992; 7: 606-613.

33. Reynolds SD, Hong KU, Giangreco A, et al. Conditional 
clara cell ablation reveals a self-renewing progenitor function of pulmonary neuroendocrine cells. Am J Physiol 2000; 278: L1256-L1263.

34. Singh G, Katyal SL. Clara cells and Clara cell $10 \mathrm{kD}$ protein (CC10). Am J Respir Cell Mol Biol 1997; 17: 141-143.

35. Warburton D, Wuenschell C, Flores-Delgado G, Anderson K. Commitment and differentiation of lung cell lineages. Biochem Cell Biol 1998; 76: 971-995.

36. Boers JE, den Brok JL, Koudstaal J, Arends JW, Thunnissen FB. Number and proliferation of neuroendocrine cells in normal human airway epithelium. Am J Respir Crit Care Med 1996; 154: 758-763.

37. Ito T. Differentiation and proliferation of pulmonary neuroendocrine cells. Prog Histochem Cytochem 1999; 34: 247-322.

38. Ito T, Ikemi Y, Ohmori K, Kitamura H, Kanisawa M. Airway epithelial cell changes in rats exposed to $0.25 \mathrm{ppm}$ ozone for 20 months. Exp Toxicol Pathol 1994; 46: 1-6.

39. Elizegi E, Pino I, Vicent S, Blanco D, Saffiotti U, Montuenga LM. Hyperplasia of alveolar neuroendocrine cells in rat lung carcinogenesis by silica with selective expression of proadrenomedullinderived peptides and amidating enzymes. Lab Invest 2001; 81: 1627-1638.

40. Johnson DE, Lock JE, Elde RP, Thompson TR. Pulmonary neuroendocrine cells in hyaline membrane disease and bronchopulmonary dysplasia. Pediatr Res 1982; 16: 446-454.

41. Asabe K, Tsuji K, Handa N, Kajiwara M, Suita S. Immunohistochemical distribution of bombesin-positive pulmonary neuroendocrine cells in a congenital diaphragmatic hernia. Surg Today 1999; 29407-412.

42. McCabe AJ, Carlino U, Holm BA, Glick PL. Upregulation of keratinocyte growth factor in the tracheal ligation lamb model of congenital diaphragmatic hernia. J Pediatr Surg 2001; 36: 128-132.

43. Hong KU, Reynolds SD, Giangreco A, Hurley CM, Stripp BR. Clara cell secretory protein-expressing cells of the airway neuroepithelial body microenvironment include a label-retaining subset and are critical for epithelial renewal after progenitor cell depletion. $\mathrm{Am}$ J Respir Cell Mol Biol 2001; 24: 671-670.

44. Borthwick DW, Shahbazian M, Todd Krantz Q, Dorin JR, Randell SH. Evidence for stem-cell niches in the tracheal epithelium. Am J Respir Cell Mol Biol 2001; 24: 662-670.

45. Stripp BR, Maxson K, Mera R, Singh G. Plasticity of airway cell proliferation and gene expression after acute naphthalene injury. Am J Physiol 1995; 269: L791-L799.

46. Van Winkle LS, Buckpitt AR, Nishio SJ, Isaac JM, Plopper CG. Cellular response in naphthaleneinduced Clara cell injury and bronchiolar epithelial repair in mice. Am J Physiol 1995; 269: L800-L818.

47. Guo J, Yi ES, Havill AM, et al. Intravenous keratinocyte growth factor protects against experimental pulmonary injury. Am J Physiol 1998; 275: L800-L805.

48. Alison MR. Assessing cellular proliferation: what's worth measuring? Hum Exp Toxicol 1995; 14: 935-944.

49. Kasper M, Haroske G. Alterations in the alveolar epithelium after injury leading to pulmonary fibrosis. Histol Histopathol 1996; 11: 463-483.

50. Uhal BD. Cell cycle kinetics in the alveolar epithelium. Am J Physiol 1997; 272: L1031-L1045.

51. Scholzen T, Gerdes J. The Ki-67 protein: from the known and the unknown. $J$ Cell Physiol 2000; 182: 311-322.

52. Johnston CJ, Finkelstein JN, Oberdorster G, Reynolds SD, Stripp BR. Clara cell secretory proteindeficient mice differ from wild-type mice in inflammatory chemokine expression to oxygen and ozone, but not to endotoxin. Exp Lung Res 1999; 25: 7-21.

53. Chen LC, Zhang Z, Myers AC, Huang SK. Cutting edge: Altered pulmonary eosinophilic inflammation in mice deficient for Clara cell secretory $10-\mathrm{kDa}$ protein. J Immunol 2001; 167: 3025-3028.

54. Stripp BR, Reynolds SD, Plopper CG, Boe IM, Lund J. Pulmonary phenotype of CCSP/UG deficient mice: a consequence of CCSP deficiency or altered Clara cell function? Ann N Y Acad Sci 2000; 923: 202-209.

55. Pilon AL. Rationale for the development of recombinant human $\mathrm{CC} 10$ as a therapeutic for inflammatory and fibrotic disease. Ann N Y Acad Sci 2000; 923: 280299.

56. Arsalane K, Broeckaert F, Knoops B, Wiedig M, Toubeau G, Bernard A. Clara cell specific protein (CC16) expression after acute lung inflammation induced by intratracheal lipopolysaccharide administration. Am J Respir Crit Care Med 2000; 161: 1624-1630.

57. Lensmar C, Nord M, Gudmundsson GH, et al. Decreased pulmonary levels of the anti-inflammatory Clara cell $16 \mathrm{kDa}$ protein after induction of airway inflammation in asthmatics. Cell Mol Life Sci 2000; 57: 976-981.

58. Bernard AM, Roels HA, Buchet JP, Lauwerys RR. Serum Clara cell protein: an indicator of bronchial cell dysfunction caused by tobacco smoking. Environ Res 1994; 66: 96-104.

59. Linnoila RI, Szabo E, DeMayo F, Witschi H, Sabourin C, Malkinson A. The role of $\mathrm{CC10}$ in pulmonary carcinogenesis: from a marker to tumor suppression. Ann N Y Acad Sci 2000; 923: 249-267.

60. Roehlecke C, Kuhnt AK, Fehrenbach H, Werner C, Funk RH, Kasper M. Resistance of L132 lung cell clusters to glyoxal-induced apoptosis. Histochem Cell Biol 2000; 114: 283-292.

61. Puchelle E, Peault B. Human airway xenograft models of epithelial cell regeneration. Respir Res 2000; 1: 125128.

62. Busse W, Elias J, Sheppard D, Banks-Schlegel S. Airway remodeling and repair. Am J Respir Crit Care Med 1999; 160: 1035-1042.

63. Van Winkle LS, Evans MJ, Brown CD, Willits NH, Pinkerton KE, Plopper CG. Prior exposure to aged and diluted sidestream cigarette smoke impairs bronchiolar injury and repair. Toxicol Sci 2001; 60: 152-164.

64. Ware LB, Folkesson HG, Matthay MA. Keratinocyte growth factor increases alveolar epithelial wound healing in vitro. FASEB J 1998; 12: A778.

65. Wang Y, Jayr C, Folkesson HG, Matthay MA. Alveolar epithelial fluid transport can be upregulated simultaneously in rats by two different mechanisms. Chest 1999; 116: 98S-100S.

66. Van Scott MR, Hester S, Boucher RC. Ion transport by rabbit nonciliated bronchiolar epithelial cells (Clara cells) in culture. Proc Natl Acad Sci USA 1987; 84: 5496-5500.

67. Van Scott MR, Penland CM, Welch CA, Lazarowski E. Beta-adrenergic regulation of $\mathrm{Cl}$ - and $\mathrm{HCO}_{-}-$ secretion by Clara cells. Am J Respir Cell Mol Biol 1995; 13: 344-351. 